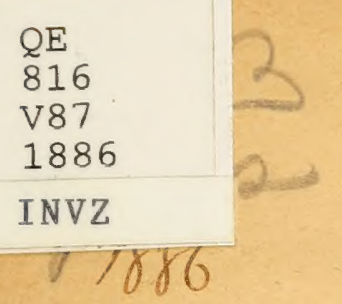

Huchony n. Vogdes

Ascriftion of o hew custacean from che

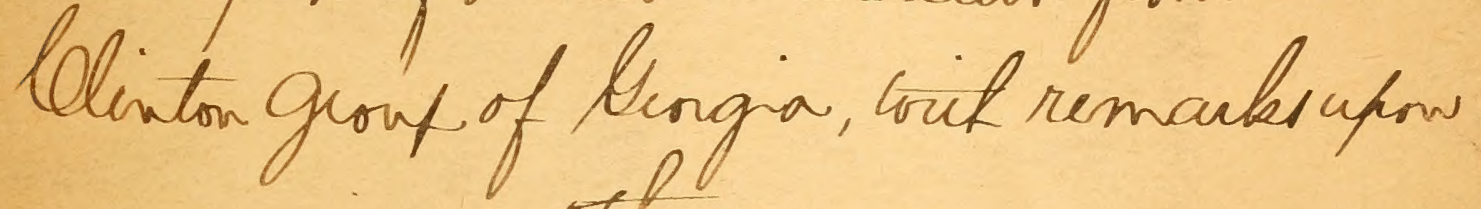
othus. 





\section{Description of a New Crustacean}

187
1886

INVZ

FROM THE-

\section{CLINTON GROUP OF GEORGIA,}

WITH REMARKS UPON OTHERS.

BY ANTHONY W. VOGDES,

U. S. Army.

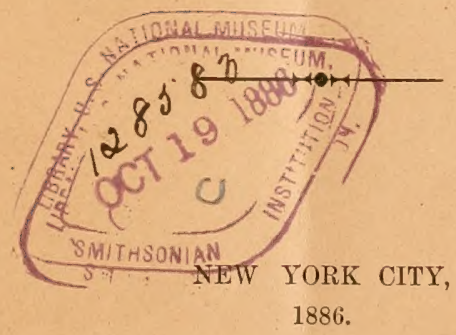





\section{DESCRIPTION OF A NEW CRUSTACEAN FROM THE CLINTON GROUP OF GEORGIA, WITH REMARKS UPON OTHERS. \\ BY ANTHONY W. VOGDES, U. S. A.}

\section{Encrinurus Americanus, Vogdes (n. s.)}

Pygidium elongated-triangular in form, strongly arched on the anterior border and very convex, produced behind forming a muronate extension. Length $10 \mathrm{~mm}$., greatest width $8 \mathrm{~mm}$., or nearly $\frac{3}{4}$ as wide as long.

$\Lambda x$ is narrowly elongated, flattened on the surface and sharply pointed behind, marked by 20 or more axial rings ; the first 13 extend entirely across, the others appearing only as notches on the sides, obscurely indicated in the specimens before us. The axis has a central row of nodes, which appear on the $1,6,9$ and 12 ring, and possibly on others.

The lateral lobes are marked by six pairs of ribs, the anterior three of which are distinct and free at their outer extremities, the other three being united at their outer ends, the posterior pair being parallel to and appearing almost as a part of the axis. The ribs are abruptly directed backward. and distinctly separated from each other by rather deep grooves, they gradually decrease in size as they approach the termination of the pygidium, being rather flat on the surface. The first pair originate almost opposite the first axial ring, the second between the 2 and 3 , the third between the 5 and 6 , the fourth between the 7 and 8 , the fifth pair run sub-parallel to the axis and the sixth pair are only separated from it by a shallow dorsal furrow.

This species approaches Encrinurus elegantulus, Billings (Catalogue Silurian Foss. Anticosti, p. 62), in general form, the axis of this species has 24 axial ring of which the first 8 or 9 extend entirely across it, the others being represented by elongated pits on each side, but it lacks the nodes. The lateral lobes of Encrinurus elegantulus are marked with five pair of ribs, the first four being free at their extremities, the fifth pair being slightly curved outwards, and conveging towards the axis 
they unite behind it, and continue as two short sharp spines. Between the fifth rib and the side of the axis there is a narrow smooth space with a faint groove on the inside, it extends round the apex of the axis and seems to be the rudiments of a sixth pair of ribs.

The principal differences between these species lies in the character of the lateral lobes, Encrinurus Americanus having three free and three united ribs in the pygidium; whereas $E n$ crinurus elegantulus the first four are free and the other two unite at their extremities, the side ribs originate at the first axial ring, the second pair at the second, the third pair at the fourth, and the fourth pair at the sixth; whereas in the new species the third pair originate between the 5 and 6 axial ring, and the fourth pair between the 7 and 8 . The minor differences with regard to the nodes on the axis may be due to the state of preservation.

The pygidia of Zethus verrucosus and Zethus bellatula described and figured by Dr. Volborth (Russ. Mineral. Gesellsch Vehandl., 1848, p. 4, pl. 1, figs. 3, 4 and 7), are in general form similar to those of Encrinurus Americanus and Encrinurus elegantulus. They all have from 4 to 6 side ribs, the anterior ones being free, and the last two or three united at their extremities in rear of the axis. The axis in the Russian species has from 16 to 18 axis rings, the first 4 or 5 anterior ring only bearing side ribs, whereas the American species has from 20 to 24 rings, the first 8 to 13 rings extending across it, the side lobes extending down in one species at least to the 8 arial ring.

The Russian species have a notched axis, with nodes along the smooth central part.

Geological Position.-Clinton Group, Taylor's Ridge, west of Catoosa Station, Catoosa Co., Georgia.

Calymene rostrata, Vogdes.

Calymene rostrata, Vogdes, 1879, Am. Jour. Sc., Art. III, vol. xviii, p. 477. Calymene rostrata, Vogdes, 1880, Acad. Nat. Sc., Phila., Proc., p. 176, figs. 1-2.

This species differs in one aspect from the usual forms classed under the genus Calymene, in having a projecting process aris- 
ing directly from the cephalic shield in front of the glabella, and in this respect resembles Homalonotus rhinotropis of Angelin, a species which has been referred by Salter, in his Monograph of British Trilobites, to $H$. Knightii. Salter says "the front Fig. 1.

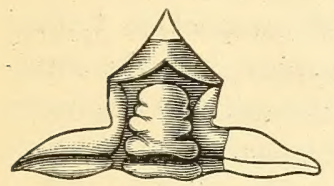

margin is of most singular structure and may be described as tricuspid. The narrow edge is so deeply indented, and at the same time folded, that the front portion overhangs the rostral shield, forms one projecting angle flanked by two smaller Calymene rostrata Vogdes. The glabella and fixed cheeks showing the projecting prucess.

projections opposite the axial furrows, exactly like the salient and re-entering angles of a fortification." Our species has only the central triangular projection, the margins of which are deflected, and the marginal border unites and forms a triangular projection, directly in front and on the median line.

The following characteristics are drawn from three specimens, consisting of the glabella and fixed checks, and many pygidia found associated with them at the same locality.

The glabella is convex and widens out posteriorly, being contracted in front; the sides are marked with three lobes, the basal one large, the middle lobe nearly spherical, the third is somewhat obscurely defined. The fixed cheeks aro separated from the glabella by deep dorsal furrows, but opposite the eyes the furrows are restricted by a buttress thrown across it, nearly touching the middle side lobes; the cheeks are gibbous but not elevated above the glabella, they are narrow along the sides of the glabella and widen out laterally from the eyes. The facial sutures cut the posterior angles of the head, but anteriorly from the eyes these lines rui almost straight with a slight tendency outward, and pass over the margin. The neck furrow is continued nearly to the posterior angles of the head. The frontal limb is triangular in outline, and prolonged into a prominent projection, the bourrelet of the limb is defined by a triangular ridge which forms the base of the projection. The projection is formed by the thickening of the crust and by the union of the outer marginal borders along the median line, it is pointed and 
has its sides deflected. The space between the front of the glabella and the base of the projection is somewhat depressed.

The pygidium is obtusely triangular, with the front greatly arehed in uncrushed specimens, but this character seems to be confined to the medium-sized specimens; the larger forms are not so much arched, and correspond in this respect to typical pygidia of C.blumenbachii. The axis occupies along the anterior border about onc-third of the width of the tail, and gradually tapers posteriorly into an obtuse point; it is marked with about eight or nine artieulations, the anterior one being slightly arched forwards, but the others are extended almost straight across it. The dorsal furrows are well defined. The lateral lobes are marked with five pairs of ribs, four of which are grooved and double half-way up; they are contracted along the dorsal fur. rows, but widen out laterally. The ribs curve downwards and backwards, and are separated from each other by well-defined groores, the last pair unite and form a ridge extending Fig. 2.

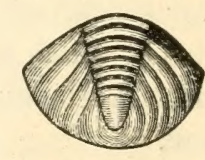

Calymene rostrata Vogdes. The pygidium usually fuund associated with the head. around the posterior termination of the axis.

Geological Position.-Clinton Group, Taylor's Ridge, near Catoosa Station; and also at Dug Gap, Georgia.

Among the trilobite specimens which I have collected in Georgia, there are three movable cheeks and one pygidium showing a strong resemblance to the same parts of Calymene Clintoni as figured by Prof. Hall in Pal. N. Y., vol. ii, pl. 66 a, fig. 5. These fragments were found associated with two glabellæ, having characteristies not shown by the illustrations of the species just referred to ; therefore, for the purpose of comparison, I carried the speciniens to the American Museum, and through the courtesy of Prof. Whitfield was enabled to study the trilobites found in the Clinton Group of New York. The Georgia forms are almost identical with those of New York, but show some variations from the typical C. Clintoni; I shall, therefore, describe these fiagments. 
Calymene Clintoni Vanuxem.

Hemicrypturus Clintoni, Vanuxem, 1842, Geol. N. Y., 3d Dist., p. 79.

Calymene Clintoni, Hall, 1852, Pal. N. Y., vol. ii, p. 298, pl. 66 a, figs. 5 a-t.

Calymene Clintoni, Rogers, 1858, Geol. Sur., Penn., vol. ii, p. 823, fig. 637.

Calymene Clintoni, Vogdes, 1880, Acad. Nat. Sc., Phila., Proc., 1). 178, tigs. 3-4.

Glabella slightly convex, the base broad, so as to form a nearly equilateral triangle. The sides are marked with three lobes, the posterior one being twice as large as the middle lobe, but the anterior one is ill-defined. The dorsal furrows are deep. The occipital ring triangular in front, and narrowing out laterally. The frontal limb is broad, and equal to half the length of the glabella, and arched in front. It is worthy of remark that this character is not common to the minute glabella found in the same beds. The fixed cheeks have a buttress thrown across

Fir. 3. them extending along the sides of the giabella, but


this does not elevate them above it. The movalle cheeks are triangular in outline, and posteriorly cxtended into spines, and correspond to those figured by Prof. Hall, Pal. N. Y., rol. ii, pl. 66 a, fig. 5, c. They are convex laterally along their inner half, and grooved near the outer margin. calymene rlintoni which is defined by a raised border. 'I'he pygibella and fixed dium is triangular in outline, and resembles the
cheeks showing the cheeks showing the
wide froutal limb. figure of this part given by Prof. Hall, Pal. N. Y., Fig. 4. vol. ii, pl. lxvi a, fig. 5 d, except in size. The

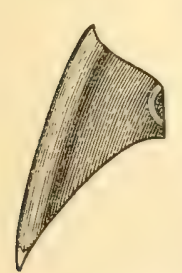
axis is marked with about eight articulations. The lateral lobes are not marked with ribs, as usual in Calymene, and in this respect the pygidium bears some resemblance to that of $C$. arago and $C$. salteri, two European forms found in the Lower Silurian, and descsibed by Rouault in the Bulletins of the Geol. Soc. of France, vols. vi and viii, Colymene Clintoni V a n $\mathrm{xem}$. The 1848-51.

movable cheek.

Geological Position.-Clinton Gromp, Catoosa Station; also in the Hematitic bed at Dug Gap, Georgia. 





